This book will change no minds. But it may encourage us to listen to those with less strident and extreme positions, who know a real dilemma when they see it, who refuse easy choices. Among the human primates, at least, they are the main ones who have been voiceless in the controversy so far. An evolutionary virologist, dismayed by the viral risk of organ transplants from baboons to humans, says of a surgeon that he "may say that he sees no real ethical issues here.... But if you don't see them, then you're the wrong person to be making the decision. Maybe this is not an area to be decided by transplant surgeons at all."

\title{
Coming plagues?
}

\section{Robert Desowitz}

The Hot Zone. By Richard Preston. Random House/Doubleday: 1994. Pp. 336, $\$ 23, £ 14.99$.

POGO's seminal observation (for those of you who remember Pogo) that "we have met the enemy and they is us" could equally apply to viral biology as to human self-destructiveness. By its insinuation into the host's genome, the virus becomes, in the genetic sense, as much as the host as the host itself. Sometimes this splice of life is clinically quiescent; sometimes it causes an annoying but not life-threatening illness; sometimes it is fatal. And there are two viruses that are man's worst nightmare, Marburg and Ebola.

Marburg and Ebola, filoviruses related to the influenza virus, strike humans with an unparalleled swiftness and destructiveness. The fatality rate is high, especially for Ebola, which kills more than 90 per cent of infected people. The course of the disease is horrible, with the explosive invasion virtually lysing its victim. There is no known cure, and no vaccine or other prophylactic. The viruses are presumed to be zoonotic agents but the natural host, or hosts, remains unidentified. The mechanism(s) of transmission is imperfectly understood. These are viruses surrounded by mystery, the mystery being even more ominous because of the uneasy suspicion that they may have the potential to break out and become "Doomsday bugs".

Marburg and Ebola are, in the literary sense, highly 'photogenic' pathogens that have been awaiting their biographer. Richard Preston attempts to fulfil this role in The Hot Zone. He adopts the docudrama format to tell two stories: the people story and the monkey story. The people story begins with a French expatriate

The culprit - Ebola, one of the group of filoviruses and the cause of Ebola fever.

employee of a Kenyan sugar plantation who takes his African girlfriend on a weekend's holiday to Mount Elgon, where they visit Kitum cave. A week later he sickens, becomes progressively more ill and dies, haemorrhaging from all his bodily orifices. A doctor who attends him develops the same symptoms and dies. Blood is drawn and sent to the Centers for Disease Control in Atlanta, Georgia, where a diagnosis of Marburg virus is made. Seven years later, in 1987, a tenyear-old Danish boy visits his parents who work for a Kenyan relief organization. The family goes on an outing to Kitum cave and shortly afterwards the boy falls sick and dies. The US Army Medical Research Institute of Infectious Diseases, Maryland, takes a blood sample and discovers that it is positive for Marburg. The boy's parents and sister are unaffected, as was the Frenchman's girlfriend. An intensive study of Kitum cave and its flora and fauna fails to reveal the virus. Meanwhile, Africans in remote villages in Zaïre are dying of Ebola. Another intensive expedition is mounted but again fails to find Ebola's reservoir.

The monkey story, which makes up the longest segment of the book, describes a killing outbreak of infectious disease in monkeys held in a commercial facility in Reston, Virginia, about ten miles from Washington DC. These were crab-eating macaques imported from the Philippines. US Army virologists diagnose Ebola. But what is this African virus doing in Philippine monkeys and why isn't it killing the animal attendants who develop antibodies to the virus but remain asymptomatic? The US Army comes in and "nukes" the monkey house.

Preston's writing is rich in such 'army speak': the virus containment facility is the "hot zone"; the human containment facility is "the Slammer". The book is also rich in 'pseudo-science speak': the virus "jumps" and "expands to burn"; the replicating viruses are "blobs" and "fat bricks" bursting from their host cells; the "healthy monkeys went nuts". It is a style of writing that complements the drama of his story. It is also a style of writing that may make you cringe.

The real problem with this book is not Preston's writing style or his lack of adequate insights into viral biology. It is his superficiality and failure to address the immensely important issues that his story illuminates. Does he not get an uneasy feeling, as I do, that military organizations are the custodians of what is considered to be the most lethal pathogen of humans - a pathogen that with a bit of genetic tinkering could become the Andromeda strain? Is he not concerned that there were no contingency plans or laws to enable authorities to deal rapidly and effectively with a potential outbreak of a highly pathogenic agent? Or to prevent the agent from entering the United States in the first place? After the Reston monkey-house disaster the same company imported the same species of monkey from the same place with the same result - virtually all the monkeys died of an Ebola or Ebola-like viral infection. Why does he not ask why there is apparently so little research on so lethal an organism about which so little is known?

For all its shortcomings, this is a powerful book. It will scare the hell out of people. But to my mind the unattended issues of public health and research are almost as scary as the virus itself.

Robert Desowitz is in the Department of Protozoology, Prince Leopold Institute of Tropical Medicine, Nationalestraat 155, B2000 Antwerp, Belgium. From 15 January 1995 he will be in the Department of Tropical Medicine and Medical Microbiology, University of Hawaii, 3675 Kilauea Avenue, Honolulu, Hawaii 96816, USA. 